\title{
MINAT LULUSAN S1 PENDIDIKAN BAHASA ARAB PTKI LAMPUNG TERHADAP LANJUT STUDI S2 PBA PASCASARJANA IAIN METRO
}

\author{
Khoirurrijal \\ IAIN METRO \\ khoirurijal@yahoo.com \\ Abdul Mujib \\ IAIN METRO \\ abdul.mujib1082@yahoo.com
}

\begin{abstract}
Cost readiness is a picture of a good economic situation. The family's economic situation is closely related to children's learning. This, in line with the opinion of Slameto, states that children who are learning must meet their basic needs for learning facilities. The learning facilities can only be fulfilled if the family has enough money. That means, a person's economic situation will influence his choice of education to carry out further studies. Universities should observe income trends, personal savings, and banks as services to help finance education. This will affect the number of prospective students who will carry out further studies and can take steps to redesign, reposition, and reassign the work program quickly. Therefore, according to Slameto that the family economy is related to children who will study further, because learning facilities can only be fulfilled if the family has enough money. Language readiness is the second supporter besides cost readiness. Therefore, to enter Postgraduate, there are Arabic and English language test requirements, in addition to the TPA test and knowledge about the subject matter. This was stated in the SOP of the IAIN Metro Postgraduate New Student Registration. Support from parents or family is very important. This is according to Slameto's opinion that the Family is the first and foremost educational institution. Family that is very big means for education in small size, but it is to determine education in large measure, namely the education of the nation. Or in other words that the family can greatly influence the future study of prospective graduate students. The desire factor to improve knowledge and worship is one of the motivations for further study. This is according to Slameto's opinion, that motivation is a psychological factor in a person. Someone has needs at a time. There are biological needs, which arise from forced circumstances such as hunger, thirst, or feeling uncomfortable. Other needs are psychological, arising from the need to be recognized, valued, or belonging.
\end{abstract}

Key Words: Interest in S1 PBA Graduates, Continued PBA Study

\begin{abstract}
Abstrak
Kesiapan biaya merupakan gambaran dari keadaan ekonomi yang baik. Keadaan ekonomi keluarga erat hubungannya dengan belajar anak. Hal itu, sejalan dengan pendapat Slameto yang menyatakan bahwa Anak yang sedang belajar harus terpenuhi kebutuhan pokok kebutuhan fasilitas belajarnya.Fasilitas belajar itu hanya dapat terpenuhi jika keluarga mempunyai cukup uang. Itu artinya, situasi ekonomi seseorang akan mempengaruhi pilihan pendidikanya untuk melakukan studi lanjut. Perguruan tinggi seharusnya mengamati tren pendapatan, tabungan pribadi, dan bank sebagai pelayanan membantu pembiayaan pendidikan. Hal tersebut akan mempengaruhi jumlah calon mahasiswa yang akan melakukan studi lanjut serta dapat mengambil langkah-langkah untuk merancang ulang, mereposisi, dan menetapkan kembali program kerja dengan cepat.Oleh karena itu, menurut Slameto bahwa ekonomi keluargaerat hubunganya
\end{abstract}


dengan anak yang akan studi lanjut belajar,karena fasilitas belajar hanya dapat dipenuhi jika keluarga mempunyai cukup uang. Kesiapan bahasa merupakan pendukung kedua disamping kesiapan biaya. Oleh karena itu untuk masuk Pascasarjana ada persyaratan tes bahasa Arab maupun bahasa Inggris, selain tes TPA dan pengetahuan tentang keprodian. Hal itu telah tercantum dalam SOP pendaftaran mahasiswa baru Pascasarjana IAIN Metro. Dukungan dari orang tua atau keluarga sangat penting. Hal itu sesuai pendapat Slameto bahwa Keluarga adalah lembaga pendidikan yang pertama dan utama. Keluarga yang sangat besar artinya untuk pendidikan dalam ukuran kecil, tetapi bersifat untuk menentukanpendidikan dalam ukuran besar, yaitu pendidikan bangsa. Atau dengan kata lain bahwa keluarga dapat sangat mempengaruhi akan studi lanjut bagi calon mahasiswa Pascasarjana. Faktor keinginan untuk meningkatkan ilmu dan Ibadah adalah salah satu motivasi untuk lanjut studi. Hal itu sesuai pendapat Slameto, bahwa motivasi merupakan faktor psikologis seseorang. Seseorang mempunyai kebutuhan pada suatu saat. Ada kebutuhan biologis, yang muncul dari keadaan yang memaksa seperti rasa lapar, haus, atau merasa tidak nyaman. Kebutuhan lainnya bersifat psikologis, muncul dari kebutuhan untuk diakui, dihargai, ataupun rasa memiliki.

Kata kunci: Minat Lulusan S1 PBA,Lanjut studi PBA

\section{Pendahuluan}

Pendidikan merupakan suatu proses dalam rangka mempengaruhi manusia agar dapat menyesuaikan diri sebaik mungkin terhadap lingkungannya."Pada dasarnya pertumbuhan dan perkembangan manusia tergantung pada dua unsur yang saling mempengaruhi, yaitu bakat yang telah dimililki sejak lahir akan tumbuh dan berkembang berkat pengaruh lingkungan, dan sebaliknya lingkungan akan lebih bermakna bila terarah pada bakat yang ada. ${ }^{1}$

Pendidikan adalah salah satu sistem di antara sistem-sistem lain dalam konteks supra-sistem (bangsa dan negara). Di satu pihak, pendidikan sebagai satu system yang melayani sistem-sistem lain dalam mendidik dan melatih Sumber Daya Manusia (SDM) yang dibutuhkan sistem-sistem itu. Di lain pihak, pendidikan juga mempunyai sub-sub sistem yang terkait satu dengan lain, baik itu bernama jalur, jenjang dan jenis maupun bernama satuan pendidikan. Subsub itu bukan hanya terkait satu dengan yang lain, tetapi juga melayani yang lain. Sebagaimana diketahui di dalam UUSPN No. 20 tahun 2003, pasal 1 bahwa sumber daya manusia dikembangkan dan dihasilkan melalui pendidikan yang pada hakekatnya adalah usaha sadar dan terencana untuk mewujudkan suasana belajar dan proses pembelajaran agar peserta didik secara aktif mengembangkan potensi dirinya untuk memiliki kekuatan spritual keagamaan, pengendalian diri, kepribadian, kecerdasan, akhlak mulia, serta keterampilan yang diperlukan dirinya, masyarakat, bangsa dan negara. ${ }^{2}$ Dengan demikian, pendidikan berfungsi sebagai alat yang strategis dalam pengembangan sumber daya manusia.

${ }^{1}$ Oemar Hamalik, Proses Belajar Mengajar, (Jakarta: Bumi Akasara, 2004), h. 79

2 UUSPN No. 20 Tahun 2003 
Dalam proses pendidikan pembangunan sumber daya manusia, tidak hanya sekedar menyiapkan sarana-sarana pendidikan secara fisik, namun mencakup non fisik, termasuk di dalamnya ketersediaan tenaga profesional di bidangnya. Pasal 31 UUD Negara Republik Indonesia tahun 1945 mengamanatkan bahwa (1) Setiap Warga Negara berhak mendapatkan pendidikan, (2) Pemerintah mengusahakan dan menyelenggarakan suatu sistem Pendidikan Nasional yang diatur dalam Undang Undang, (3) Setiap warga Negara wajib mengikuti Pendidikan Dasar dan Pemerintah wajib membiayai, (4) Pemerintah mengusahakan dan menyelenggarakan suatu sistem Pendidikan Nasional yang meningkatkan keimanan dan ketakwaan serta akhlak mulia dalam rangka mencerdaskan kehidupan Bangsa yang diatur dengan Undang Undang.Bahwa "pendidikan memang dipandang mempunyai peranan yang besar untuk menciptakan masa depan yang gemilang yang menjadi idaman kita bersama. Hal ini dimungkinkan karena dengan usaha yang terus-menerus ditingkatkan melalui pembangunan di bidang pendidikan" ${ }^{3}$

Proses belajar mengajar merupakan inti dari proses pendidikan secara keseluruhan dan pendidik sebagai pemegang peranan utama. Harapan setiap guru adalah agar peserta didiknya dapat mencapai hasil belajar yang sebaikbaiknya sesuai dengan tujuan yang telah digariskan dalam proses belajar mengajar di sekolah. Namun kenyataan yang dihadapi tidak selalu menunjukkan apa yang diharapkan itu dapat terealisir sepenuhnya. Banyak peserta didik yang menunjukkan tidak dapat mencapai hasil belajar sebagai mana mestinya yang diharapkan oleh pendidik.

Salah satu faktor yang mempengaruhi belajar adalah minat. Tanpa adanya minat rasanya tidak mungkin terjadi proses belajar dengan baik. Dapat dibayangkan apabila seseorang tidak memiliki minat untuk melakukan sesuatu pekerjaan, pasti ia tidak sungguh-sungguh dalam melaksanakannya dan akhirnya hasilnya pun tidak optimal atau rendah. Begitu pula adalam proses pembelajaran, minat sangat berperan penting dalam rangka meningkatkan aktivitas belajar anak. Dengan adanya minat, seseorang akan lebih bersemangat dalam belajar, karena belajar itu merupakan aktivitas atau serangkaian kegiatan baik itu dilakukan individu maupun kelompok untuk memperoleh hasil belajar yang baik, sehingga apabila dalam kegiatan pembelajaran seorang tidak berbuat sesuatu yang seharusnya dikerjakan, maka perlu diteliti penyebabnya. Minat adalah "suatu rasa lebih suka dan rasa ketertarikan pada suatu hal atau aktivitas, tanpa ada yang menyuruh. Minat pada dasarnya adalah penerimaan akan suatu hubungan antara diri sendiri dengan sesuatu di luar dirinya semakin kuat atau dekat hubungan antara diri sendiri dengan sesuatu di luar dirinya, maka semakin besar minat yang tumbuh di dalam dirinya". ${ }^{4}$

${ }^{3} \mathrm{Abu}$ Ahmadi dan Nur Uhbiyati, Ilmu Pendidikan, (Jakarta: Rineka Cipta, 2017), h. 78

4Slameto, Belajar dan Faktor-Faktor yang Mempengaruhinya, (Jakarta: Renika Cipta, 2013), h. 
Berdasarkan pendapat di atas, dapat diambil pengertian bahwa minat adalah rasa suka, rasa ketertarikan dan rasa senang terhadap suatu hal atau aktivitas yang timbul dari diri seseorang berdasarkan kesadaran sendiri pada waktu dan situasi tertentu.

Minat timbul karena adanya informasi atau pengetahuan tentang suatu pelajaran, benda atau situasi tertentu. Jadi, ketekunan dan keuletan belajar oleh anak akan sangat ditentukan oleh minat belajar anak itu sendiri. Tidak adanya minat anak terhadap suatu pelajaran akan menimbulkan kesulitan belajar.

Filosofi dari magister pendidikan bahasa Arab menyadarkan pada terminologi sistem pendidikan Nasional, yakni sebagai wahana Pembangunan Nasional di bidang Pendidikan bahasa Arab yang bertujuan mencerdaskan kehidupan Bangsa dan meningkatkan kualitas manusia Indonesia dalam mewujudkan masyarakat maju, adil dan makmur yang memungkinkan warganya mampu mengembangkan diri, baik berkenaan dengan aspek jasmaniyah maupun rohaniyah, kesemuanya itu dalam rangka memantapkan ketahanan Nasional serta mewujudkan masyarakat maju yang berakar pada kebudayaan Bangsa dan persatuan Nasional yang berwawasan Bhineka Tunggal Ika berdasarkan Pancasila dan UUD 1945.

Pendidikan bahasa Arab dipolakan dalam suatu model pendidikan sebagai sistem Pendidikan Tinggi Nasional yang mengemban Tri Dharma Perguruan Tinggi, yaitu Pendidikan, Penelitian, dan Pengabdian Masyarakat dengan tetap menjamin terpelihara dan berkembangnya nilai luhur budaya bangsa, menjujung tinggi nilai agama serta mengaktualisasikan nilai nilai ajarannya dalam keseluruan aspek kehidupan, terutama masyarakat dan kehidupan Ilmiyah. Oleh karena itu, sebagai Lembaga Pendidikan Tinggi Islam Negeri, merasa terpanggil untuk turut serta dalam mengembangkan dan memajukan pendidikan dan pengajaran bahasa Arab. Upaya tersebut dapat terealisasi salah satunya dengan Prodi Magister Pendidikan Bahasa Arab, mengingat Prodi Magister Pendidikan Bahasa Arab, khususnya di Wilayah Sumatera saat ini masih minim, sedangkan lulusan S1 Prodi Pendidikan Bahasa Arab, baik dari IAIN Metro maupun PTKI lainya sendiri memerlukan tempat kuliah untuk pengembangan studinya ke jenjang yang lebih tinggi lagi (S2).

Minat masyarakat terlihat ketika banyak sekali guru bahasa Arab di lembaga pendidikan Negeri maupun Swasta yang berminat untuk melanjutkan studi mereka ke Jenjang Magister. Mereka adalah para alumni Perguruan Tinggi S1 yang berprofesi sebagai Guru, Peneliti, Penerjemah, Instruktur bahasa Arab, pemandu haji dan umrah, pemandu wisata dan konsultan bahasa Arab. Jika mereka mendapatkan kesempatan belajar di Pascasarjana pada Prodi Magister Pendidikan Bahasa Arab yang betul-betul berkualitas, maka akan dihasilkan para ahli yang qualified dalam Pendidikan Bahasa Arab dan pengajarannya.

Program studi Magister Pendidikan Bahasa Arab Pascasarjana dikembangkan untuk menghasilkan lulusan Magister di bidang pendidikan dan 
bahasa Arab dengan kompetensi pendukung praktisi di bidang penerjemahan, pariwisata, dan administrasi. Lulusan dari magister Prodi Magister Pendidikan Bahasa Arab, nantinya bisa berkiprah di tengah-tengah masyarakat sebagai: Guru bahasa Arab, peneliti bahasa Arab, penerjemah lisan dan tulisan bahasa Arab - Indonesia, instruktur bahasa Arab, pemandu haji dan umrah, pemandu wisata dan konsultan bahasa Arab. Pimpinan dan jajarannya IAIN Metro Lampung menyadari sepenuhnya bahwa tuntutan sumber daya manusia sebagaimana yang dimaksud di atas dapat dipenuhi melalui program yang terarah dan berkesinambungan. Didasari pula bahwa sebagai lembaga pendidikan tinggi memiliki tanggung jawab moral untuk turut serta mempersiapkan sumber daya manusia yang berkualitas, baik untuk kepentingan IAIN Metro Lampung maupun untuk kepentingan lembagalembaga pelayanan masyarakat lainnya.

Mengingat kondisi tersebut di atas, Magister Pendidikan bahasa Arab pada Pascasarjana IAIN Metro Lampung merupakan solusi untuk menjawab kebutuhan stekholder tersebut dengan penyajian program pembelajaran yang ditawarkan. Program Studi Magister Pendidikan Bahasa Arab IAIN Metro merupakan prodi yang dipersiapkan untuk mencetak ilmuwan di bidang Pendidikan Bahasa Arab dengan profesi seperti pendidik (guru dan dosen), peneliti, tenaga ahli (profesional), penerjemah, instruktur bahasa Arab, pemandu haji dan umrah, pemandu wisata serta sebagai konsultan Bahasa Arab. Sedangkan lulusan-nya (output) tersebut, nantinya dapat dijadikan pelopor pengembangan keilmuan, teknologi pembelajaran dan mempercepat kemandirian masyarakat. Diproyeksikan kebutuhan masyarakat (stakeholder), baik lembaga pemerintah (formal) maupun non formal akan lulusan program studi PBA untuk lima tahun ke depan masih sangat tinggi, hal ini yang menjadi salah satu alasan kenapa Pascasarjana IAIN Metro mengembangkan program studi ini. Selain itu juga Prodi Magister PBA di Propinsi Lampung masih minim.

\section{Pengertian Minat}

Minat merupakan suatu kecenderungan untuk memberikan perhatian dan bertindak terdapat orang, aktivitas atau situasi yang menjadi objek dari minat tersebut dengan disertai perasaan senang. ${ }^{5}$ Pendapat lain, bahwa minat adalah kecenderungan jiwa yang tetap ke jurusan sesuatu hal yang berharga bagi seseorang. Sesuatu yang berharga bagi seseorang adalah sesuai dengan kebutuhannya. ${ }^{6}$

Minat adalah kecenderungan atau dorongan jiwa yang menambahkan kemauan dan keinginan untuk belajar serta dapat menimbulkan rasa kegembiraan individu dalam usaha belajar, minat adalah kecenderungan jiwa

${ }^{5}$ Abdurahman Shaleh dan Muhbib Abdul Wahab, Psikologi Suatu Pengantar dalam Perspektif Islam, (Jakarta: Kencana, 2016), h. 263

6Zakiah Daradjat, Metodik Khusus Pengajaran Agama Islam, (Jakarta: Bumi Aksara, 2014), h. 133 
kepada sesuatu, karena kita merasa ada kepentingan dengan sesuatu itu. ${ }^{7}$ Secara umum, minat dapat diartikan sebagai suatu kecenderungan yang menyebabkan seseorang berusaha untuk mencari ataupun mencoba aktivitas-aktivitas dalam bidang tertentu. Minat juga diartikan sebagai sikap positif terhadap aspek-aspek lingkungan. Ada juga yang mengartikan minat sebagai kecenderungan yang tetap untuk memperhatikan dan menikmati suatu aktivitas disertai rasa senang. Minat adalah perhatian yang kuat, intensif, dan menguasai individu secara mendalam untuk tekun melakukan suatu aktivitas. ${ }^{8}$ Minat studi lanjut dalam pendidikan ke jenjang berikutnya dapat membentuk sikap akademik tertentu yang bersifat sangat pribadi pada setiap mahasiswa. Oleh karena itu, minat studi lanjut ke kenjang yang lebih tinggi dapat ditumbuhkan sendiri oleh masing-masing individu. Pihak lainnya hanya memperkuat dan menumbuhkan minat atau untuk memelihara minat yang telah dimiliki seseorang, dikarenakan minat berkaitan dengan nilai-nilai tertentu. ${ }^{9}$ Oleh karena itu, merenungkan nilainilai dalam belajar sangat berguna untuk membangkitkan minat. Misalnya belajar agar lulus ujian, menjadi juara, ahli dalam salah satu ilmu, memenuhi rasa ingin tahu mendapatkan gelar atau memperoleh pekerjaan. Dengan demikian, minat belajar tidak perlu berangkat dari nilai atau motivasi yang muluk-muluk. Bila minat belajar didapatkan pada gilirannya akan menumbuhkan konsentrasi atau kesungguhan dalam belajar kejenjang yang lebih tinggi. ${ }^{10}$

Berdasarkan pendapat tersebut dapat difahami bahwa minat adalah suatu kecenderungan hati/jiwa atau kepentingan kepada sesuatu yang timbul dalam diri individu karena sesuatu itu sangat berharga atau sangat penting untuk kebutuhannya. Adanya minat anak akan mendorong peserta didik tersebut untuk memberikan perhatian yang lebih serta konsentrasi terhadap apa aya yang dipelajarinya.

Bahkan Allah sendiri telah memberikan motifasi yang besar kepada manusia ketika mereka mendapatkan hal yang menjadikannya beban di pundaknya. Maka, Allah akan memberikan kemudahan baginya bersamaan dengan kesulitan dan beban yang menimpanya, seperti firmannya dalam surat an-Nasyroh berikut ini.

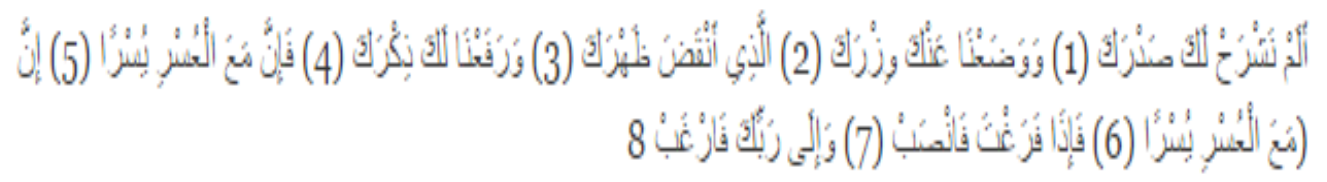

${ }^{7}$ Ahmad D. Marimba, Pengantar Filsafat Pendidikan Islam, , (Bandung: Al-Ma'arif, 1997), h. 79

8Bobbi De Porter \& Mike Hernachi, Quantum Learning: Membiasakan Belajar Nyaman dan Mentenangkan, (Kaifa: Bandung, 2003), h. 32

9Loekmono, Belajar Bagaimana Belajar, (Jakarta: BPK Gunung Mulia, 1994), h. 35

10Sudarmono, Tuntunan Metodologi Belajar, (Jakarta: Grasindo, 1994), h. 72 
Artinya : "Bukankah Kami telah melapangkan untukmu dadamu? (1), dan Kami telah hilangkan daripadamu bebanmu (2), yang memberatkan punggungmu (3), dan Kami tinggikan bagimu sebutanmu (4), karena sesungguhnya sesudah kesulitan itu ada kemudahan (5), sesudah kesulitan itu ada kemudahan (6), maka apabila kamu telah selesai dari urusanmu, kerjakanlah dengan sungguh-sungguh urusan orang lain (7), dan hanya kepada Tuhanmu lah hendaknya kamu berharap (8)."

\section{Fungsi Minat Lanjut Studi}

Minat lanjut studi dari strata 1 ke jenjang strata 2 sebagai suatu kekuatan yang bisa mendorong atau mempengaruhi seseorang untuk melakukan suatu kegiatan, memiliki fungsi-fungsi tertentu. Sebagaimana yang di kemukakan oleh Sugeng Paranto11, bahwa minat belajar lanjut studi sebagai daya penggerak organisasi manusia yang mempunyai fungsi-fungsi sebagai berikut :

1. Memperkuat aktifitas dalam mencapai suatu tujuan

2. Menimbulkan tuntutan akan terpenuhinya suatu kebutuhan

3. Menimbulkan semangat dan memberikan arah dalam melakukan pekerjaan. ${ }^{12}$

Berdasarkan pendapat di atas, menunjukkan bahwa fungsi minat belajar lanjut studi bagi seseorang sangat besar, khususnya dalam melakukan suatu kegiatan atau pekerjaan. Selain itu, minat belajar juga memiliki banyak fungsi yang kesemuanya bersatu dalam diri seseorang dan kemudian menggerakkannya untuk mencapai tujuan. Sebagai suatu kesatuan yang mendasari terjadinya perbuatan, tindakan atau aktivitas tertentu. Minat belajar lanjut studi berfungsi aktif dalam mensukseskan suatu kegiatan yang dilakukan oleh seseorang. Dalam mencapai segala tujuan dan keberhasilannya segala sesuatu dalam proses belajar mengajar, minat merupakan salah satu faktor yang memegang peran penting.

Fungsi minat sangat besar pengaruhnya terhadap belajar, karena bila kegiatan pembelajaran tidak sesuai dengan minat, peserta didik tidak akan belajar dengan sebaik-baiknya, karena tidak ada daya tarik baginya, bahkan tak segan-segan untuk tidak belajar, ia tidak memperlukan kepuasan dari pelajaran itu. Bahan pelajaran yang menarik, lebih mudah dipelajari dan disimpan, karena minat menambah kegiatan belajar. ${ }^{13}$

Demi menarik minat para pembelajar dalam proses pembelajaran, tentunya diperlukan beberapa hal yang dapat dijadikan sebagai sarana untuk menarik minat tersebut. Al-Qur'an telah diturunkan dengan gaya bahasa yang semenarik mungkin, sehingga dapat menjadi perhatian bagi ummat Muhammad saw saat diturunkannya. Selain itu, Allah telah berfirman:

11Sugeng Paranta, Psikologi Perkembangan, (Jakarta: Angkasa, 2001), h. 17.

${ }^{12}$ Ibid

13Slameto, Belajar dan Faktor-Faktor yang Mempengaruhinya, (Jakarta: Renika Cipta, 2013), h. 57 


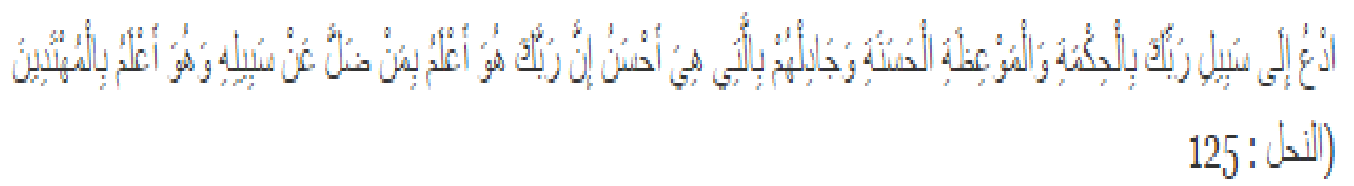

Artinya : "Serulah (manusia) kepada jalan Tuhanmu dengan hikmah, dan pelajaran yang baik dan berbantahlah mereka dengan cara yang baik. Sesungguhnya Tuhanmu Dialah yang lebih mengetahui tentang siapa yang tersesat dari jalan-Nya dan Dialah yang lebih mengetahui orang-orang yang mendapat petunjuk."

Dari ayat di atas, telah jelas bahwa seruan dakwah dan proses pembelajaran dengan hikmah atau perkataan yang tegas dan benar yang dapat membedakan antara yang haq dan yang bathil. Serta memberikan pelajaran yang baik, atau dengan memberikan teladan yang baik bagi peserta didik. Dan juga memberikan ruang diskusi untuk saling berargumen, akan tetapi jika terjadi debat atau perselisihan, maka hendaknya diselesaikan dengan penyelesaian yang baik, yaitu dengan menggunakan bahasa yang ramah, dan halus. Dengan demikian pembelajaran yang berlangsung akan menjadi menarik dan terjadi dalam suasana yang kondusif.

Tidak adanya minat seseorang anak terhadap kegiatan pelajaran akan timbul kesulitan belajar. "Ada tidaknya minat terhadap pelajaran dapat dilihat dari cara anak mengikuti pelajaran, lengkap tidaknya catatan, memperhatikan garis miring tidaknya dalam pelajarana itu". ${ }^{14}$

Selain itu, minat belajar studi lanjut pada anak dapat dilihat dengan adanya fenomena-fenomena atau gejala-gejala yang nampak atau dilakukan oleh seseorang selama proses belajar atau sebelum memasuki perguruan tinggi. "Suatu minat dapat diekspresikan melalui suatu pernyataan yang menunjukkan bahwa seseorang lebih mungkin suatu hal dari pada hal lainnya, dapat pula dimanifestasikan melalui partisipasi dalam suatu aktifitas" ${ }^{15}$

\section{Faktor-faktor Yang Mempengaruhi Studi Lanjut}

\section{Faktor-faktor budaya}

Faktor-faktor budaya memberikan pengaruh paling luas pada keinginan dan perilaku Mahasiswa.

a. Budaya (culture)

Budaya adalah bentuk jamak dari kata budi dan daya yang berarti cinta, karsa dan rasa. Kata budaya sebenarnya berasal dari bahasa Sansekerta, budhayah yaitu bentuk jamak dari kata buddhi yang berarti budi atau akal. Dalam bahasa Inggris, kata budaya berasal dari kata

${ }^{14}$ Abu Ahmadi dan Widodo Supriyono, Psikologi Belajar, (Jakarta: Rineka Cipta, 2004), h. 83

15 Slameto, Belajar dan Faktor-Faktor..., h.180 
culture, dalam bahasa Belanda diistilahkan dengan kata cultuur, dalam bahasa Latin, berasal dari kata colera. Colera berarti mengolah, mengerjakan, menyuburkan tanah (bertani). ${ }^{16}$ Menurut E. B. Tylor, budaya adalah "suatu keseluruhan kompleks yang meliputi pengetahuan, kepercayaan, kesenian, moral, keilmuan, hukum, adat istiadat dan kemampuan lain serta kebiasaan yang didapat oleh manusia sebagai masyarakat". ${ }^{17}$ Jadi, budaya adalah mengolah atau mengerjakan sesuatu agar terbiasa, atau menjadikan adat kebiasaan.

Budaya adalah penyebab paling mendasar dari keinginan dan perilaku seseorang. Budaya merupakan susunan nilai-nilai dasar, persepsi, keinginan, dan perilaku yang dipelajari anggota suatu masyarakat dari keluarga dan institusi penting lainnya. Menentukan Studi lanjut ke jenjang pendidikan S2 yang diinginkan mahasiswa dapat dilakukan dengan berusaha selalu mencoba menemukan pergeseran budaya yang ada.

b. Sub kebudayaan

Sikap kebudayaan mengandung sub kebudayaan (subculture) yang lebih kecil, atau kelompok orang-orang yang mempunyai sistem nilai yang sama berdasarkan pengalaman dan situasi kehidupan yang sama. Sub kebudayaan meliputi kewarganegaraan, agama, kelompok, ras, dan daerah geografis. Banyak sub kebudayaan yang membentuk segmen pasar terkait dengan program studi pendidikan Bahasa Arab sangat penting, dan orang pemasaran seringkali merancang produk dan program pemasaran yang disesuaikan dengan kebutuhan calon pengguna yaitu mahasiswa S2.

c. Kelas sosial (social culture)

Hampir setiap masyarakat memiliki beberapa bentuk struktur kelas sosial. Kelas-kelas sosial (social classes) adalah bagian-bagian masyarakat yang relatif permanen dan tersusun rapi yang anggotaanggotanya mempunyai nilai-nilai, kepentingan, dan perilaku yang sama. Kelas sosial tidak ditentukan oleh satu faktor saja, misalnya pendapatan, tetapi ditentukan sebagai suatu kombinasi pekerjaan, pendapatan, pendidikan, kesejahteraan, dan variabel lainnya. Dalam beberapa sistem sosial, anggota-anggota dan kelas-kelas yang berbeda menggunakan aturan- aturan tertentu dan tidak dapat mengubah posisi sosial masyarakat. Orang-orang dalam kelas sosial cenderung menunjukkan perilaku membeli yang serupa.

16Elly M. Setiadi, dkk, Ilmu Sosial dan Budaya Dasar, (Jakarta: Kencana, 2011), h. 27 17Ibid 


\section{Konsep Bahasa Arab di Dunia Modern}

Bahasa Arab (عربية اللغة al-lughah al-'Arabìyyah), atau secara mudahnya Arab (عربي `Arabī), adalah sebuah bahasa Semitik yang muncul dari daerah yang sekarang termasuk wilayah Arab Saudi. Bahasa ini adalah sebuah bahasa yang terbesar dari segi jumlah penutur dalam keluarga bahasa Semitik.

Bahasa ini berkerabat dekat dengan bahasa Ibrani dan bahasa Aram. Bahasa Arab Modern telah diklasifikasikan sebagai satu makrobahasa dengan 27 sub-bahasa dalam ISO 639-3. Bahasa-bahasa ini dituturkan di seluruh Dunia Arab, sedangkan Bahasa Arab Baku diketahui di seluruh Dunia Islam.

Bahasa Arab Modern berasal dari Bahasa Arab Klasik yang telah menjadi bahasa kesusasteraan dan bahasa liturgi Islam sejak lebih kurang abad ke-6. Abjad Arab ditulis dari kanan ke kiri.

Bahasa Arab telah memberi banyak kosakata kepada bahasa lain dari dunia Islam, sama seperti peranan Latin kepada kebanyakan bahasa Eropa. Semasa Abad Pertengahan bahasa Arab juga merupakan alat utama budaya, terutamanya dalam sains, matematik adan filsafah, yang menyebabkan banyak bahasa Eropa turut meminjam banyak kosakata dari bahasa Arab. ${ }^{18}$

\section{Pendidikan Bahasa Arab di Indonesia}

Sejauh ini belum ada hasil penelitian yang memastikan sejak kapan studi bahasa Arab di Indonesia mulai dirintis dan dikembangkan. Asumsi yang selama ini berkembang adalah bahwa bahasa Arab sudah mulai dikenal oleh bangsa Indonesia sejak Islam dikenal dan dianut oleh mayoritas bangsa kita. Jika Islam secara meluas telah dianut oleh masyarakat kita pada abad ke-13, maka usia pendidikan bahasa Arab dipastikan sudah lebih dari 7 abad, karena perjumpaan umat Islam Indonesia dengan bahasa Arab itu paralel dengan perjumpaannya dengan Islam. Dengan demikian, bahasa Arab di Indonesia jauh lebih "tua dan senior" dibandingkan dengan bahasa Asing lainnya, seperti: Belanda, Inggris, Portugal, Mandarin, dan Jepang.

Pendidikan bahasa Arab di Indonesia sudah diajarkan mulai dari TK (sebagian) hingga perguruan tinggi. Berbagai potret penyelenggaraan pendidikan bahasa Arab di lembaga-lembaga pendidikan Islam setidaknya menunjukkan adanya upaya serius untuk memajukan sistem dan mutunya. Secara teoritis, paling tidak ada empat orientasi pendidikan bahasa Arab sebagai berikut:

1. Orientasi Religius, yaitu belajar bahasa Arab untuk tujuan memahami dan memahamkan ajaran Islam (fahm al-maqrü'). Orientasi ini dapat berupa belajar keterampilan pasif (mendengar dan membaca), dan dapat pula mempelajari keterampilan aktif (berbicara dan menulis);

${ }^{18}$ Departemen Pendidikan Nasional, (Undang-Undang No. 20 Sistem Pendidikan Nasional Tahun 2003, Jakarta, 2003), h. 6 
2. Orientasi Akademik, yaitu belajar bahasa Arab untuk tujuan memahami ilmu-ilmu dan keterampilan berbahasa Arab (istimâ', kalâm, qirâ'ah, dan kitâbah). Orientasi ini cenderung menempatkan bahasa Arab sebagai disiplin ilmu atau obyek studi yang harus dikuasai secara akademik. Orientasi ini biasanya identik dengan studi bahasa Arab di Jurusan Pendidikan Bahasa Arab, Bahasa dan Sastra Arab, atau pada program Pascasarjana dan lembaga ilmiah lainnya;

3. Orientasi Profesional/Praktis dan Pragmatis, yaitu belajar bahasa Arab untuk kepentingan profesi, praktis atau pragmatis, seperti mampu berkomunikasi lisan (muhâdatsah) dalam bahasa Arab untuk bisa menjadi TKI, diplomat, turis, misi dagang, atau untuk melanjutkan studi di salah satu negara Timur Tengah dan sebagainya;

4. Orientasi Ideologis dan Ekonomis, yaitu belajar bahasa Arab untuk memahami dan menggunaakan bahasa Arab sebagai media bagi kepentingan orientalisme, kapitalisme, imperialisme dan sebagainya. Orientasi ini, antara lain, terlihat dari dibukanya beberapa lembaga kursus bahasa Arab di negara-negara Barat. ${ }^{19}$

Pendidikan Bahasa Arab (PBA) di Indonesia relatif sudah tersebar di berbagai UIN, IAIN, STAIN dan sebagian PTAI swasta seperti Universitas Islam Jakarta. Hanya saja, disiplin keilmuan ini masih tergolong "miskin" sumber daya manusia dan sumber-sumber studi (referensi). Sementara ini, yang tergolong memiliki SDM PBA cukup kuat adalah PBA FITK Jakarta (4 profesor, 4 doktor dan 8 Magister). Menurut pengamatan penulis, yang agak memperihatinkan, terutama bagi PBA di luar UIN Jakarta yang masih miskin SDM, adalah bagaimana lembaga-lembaga itu mampu meningkatkan kualitas SDM dan memperkaya referensi sebagai basis pembelajaran, penelitian dan pengembangan ilmu-ilmu bahasa Arab.

Di Propinsi Lampung terdapat 6 Perguruan Tinggi Keagamaan Islam (PTKI) yang menyelenggarakan pendidikan jenjang S1 Pendidikan Bahasa Arab (PBA), yaitu Institut Agama Islam Negeri (IAIN) Metro, Universitas Islam Negeri (UIN) Raden Intan Lampung, STAINU Kotabumi, IAI Ma'arif NU Metro, STIT Darul Fattah Bandar Lampung dan Sekolah Tinggi Ilmu Tarbiyah (STIT) Prengsewu.

Dari keenam Perguruan Tinggi di atas, hanya STIT Prengsewu yang belum memiliki Alumni, karena baru berjalan tiga tahun dan hanya IAIN Metro dan UIN Raden Intan Lampung yang menyelenggarakan pendidikan jenjang S2 dengan Program Studi Magister Pendidikan bahasa Arab (PBA).

Alumni PTKI, baik negeri maupun swasta memiliki peran yang strategis di masyarakat. Peran-peran strategis itu misalnya sebagai Guru, Dosen, Tokoh Agama dan Tokoh Masyarakat.

${ }^{19}$ Fajri, Perkembangan Pengajaran Bahasa Arab, h. 6 
Para Alumni S1 PBA PTKI di Lampung, tentu ada yang melanjutkan studi mereka ke jenjang S2, bahkan ada juga yang melanjutkan studi ke jenjang S3, agar mereka memiliki ilmu pendidikan dan pengajaran bahasa Arab yang luas dan mendalam.

Penelitian ini adalah penelitian tentang minat lulusan S1 PBA PTKI di Lampung terhadap studilanjut S2 di Pascasarjana IAIN Metro berikut faktor pendukung dan kendalanya. Peneliti memfokuskan pada 5 Perguruan Tinggi Keagamaan Islam Penyelenggara S1 PBA di Lampung yang sudah memiliki Alumni, yaitu: yaitu Institut Agama Islam Negeri (IAIN) Metro, Universitas Islam Negeri (UIN) Raden Intan Lampung, STAINU Kotabumi, IAI Ma'arif NU Metro dan STIT Darul Fattah Bandar Lampung. Sedangkan untuk STIT Prengsewu karena belum memiliki Alumni, maka Peneliti tidak melaksanakan penelitian di sana.

Dari temuan penelitian pada sub bab terdahulu, bahwa minat lulusan S1 Pendidikan Bahasa Arab PTKI di Lampung terhadap lanjut studi S2 Pendidikan Bahasa Arabdi Pascasarjana IAIN Metro karena adanya keinginan dari diri Alumni S1 PBA PTKI di Lampung untuk meningkatkan keilmuan mereka dalam bidang pendidikan dan pengajaran bahasa Arab dan juga karena adanya dukungan dari Orangtua mereka masing-masing.

Keinginan dari diri sendiri untuk melanjutkan studi adalah syarat utama, sedangkan dukungan dari orang tua atau juga penting. Hal itu sebagaimana sabda Nabi yang artinya dari Abdullah bin Umar r.a. berkata, Rasulullah Saw bersabda: "Keridhaan Allah itu di dalam keridhaan orang tua dan kemarahan Allah itu di dalam kemarahan kedua orang tua." (H.R. At-Tirmidzi).

Dari hadits di atas, "keridhaan orang tua merupakan keridhaan Allah dan kemarahan orang tua merupakan kemarahan Allah", maka dalam melanjutkan studi harus ada restu dan dukungan dari orang tua. Tanpa dukungan dari orang tua, maka apa yang dilakukan akan terasa kurang lengkap.

Faktor pendukung minat lulusan S1 Pendidikan Bahasa Arab PTKI di Lampung terhadap lanjut studi S2 Pendidikan Bahasa Arabdi Pascasarjana IAIN Metroadalah adanya kesiapan biaya, kesiapan bahasa, dukungan orang tua, dukungan pihak sekolah dimana mereka mengajar serta faktor keinginan untuk meningkatkan ilmu dan Ibadah.

Kesiapan biaya merupakan gambaran dari keadaan ekonomi yang baik. Keadaan ekonomi keluarga erat hubungannya dengan belajar anak. Hal itu, sejalan dengan pendapat Slameto yang menyatakan bahwa Anak yang sedang belajar harus terpenuhi kebutuhan pokok kebutuhan fasilitas belajarnya.Fasilitas belajar itu hanya dapat terpenuhi jika keluarga mempunyai cukup uang. Itu artinya, situasi ekonomi seseorang akan mempengaruhi pilihan pendidikanya untuk melakukan studi lanjut. Perguruan tinggi seharusnya mengamati tren pendapatan, tabungan pribadi, dan bank sebagai pelayanan membantu pembiayaan pendidikan. Hal tersebut akan mempengaruhi jumlah calon 
mahasiswa yang akan melakukan studi lanjut serta dapat mengambil langkahlangkah untuk merancang ulang, mereposisi, dan menetapkan kembali program kerja dengan cepat.Oleh karena itu, menurut Slameto bahwa ekonomi keluargaerat hubunganya dengan anak yang akan studi lanjut belajar,karena fasilitas belajar hanya dapat dipenuhi jika keluarga mempunyai cukup uang.

Kesiapan bahasa merupakan pendukung kedua disamping kesiapan biaya. Oleh karena itu untuk masuk Pascasarjana ada persyaratan tes bahasa Arab maupun bahasa Inggris, selain tes TPA dan pengetahuan tentang keprodian. Hal itu telah tercantum dalam SOP pendaftaran mahasiswa baru Pascasarjana IAIN Metro.

Dukungan dari orang tua atau keluarga sangat penting. Hal itu sesuai pendapat Slameto bahwa Keluarga adalah lembaga pendidikan yang pertama dan utama. Keluarga yang sangat besar artinya untuk pendidikan dalam ukuran kecil, tetapi bersifat untuk menentukanpendidikan dalam ukuran besar, yaitu pendidikan bangsa. Atau dengan kata lain bahwa keluarga dapat sangat mempengaruhi akan studi lanjut bagi calon mahasiswa Pascasarjana.

Dukungan pihak sekolah dimana mereka bekerja sebagai pendidik juga turut menentukan studi lanjut, hal itu sesuai pendapat Slameto bahwa pekerjaan seseorang ikut mempengaruhi minat dan kegiatanyang dilakukanya. Institusi perguruan tinggi mencoba mengidentifikasi kelompok-kelompok pekerja yang memiliki minat yang rata-rata lebih tinggi melakukan lanjut studi ke perguruan tinggi baik melalui penelitian maupun lembaga survay. Bahkan terkadang melakukan kerjasama dengan penerima jasa perguruan tinggi seperti lembagalembaga pendidikan yang dibutuhkan satu kelompok pekerjaan tertentu.

Faktor keinginan untuk meningkatkan ilmu dan Ibadah adalah salah satu motivasi untuk lanjut studi. Hal itu sesuai pendapat Slameto, bahwa motivasi merupakan faktor psikologis seseorang. Seseorang mempunyai kebutuhan pada suatu saat. Ada kebutuhan biologis, yang muncul dari keadaan yang memaksa seperti rasa lapar, haus, atau merasa tidak nyaman. Kebutuhan lainnya bersifat psikologis, muncul dari kebutuhan untuk diakui, dihargai, ataupun rasa memiliki. Kebanyakan kebutuhan ini tidak akan cukup kuat untuk memotivasi orang tersebut untuk bertindak pada suatu waktu tertentu. Suatu kebutuhan akan menjadi motif apabila dirangsang sampai suatu tingkat intensitas yang mencukupi.

Faktor penghambat minat lulusan S1 Pendidikan Bahasa Arab PTKI di Lampung terhadap lanjut studi S2 Pendidikan Bahasa Arabdi Pascasarjana IAIN Metro karena Alumni S1 PBA PTKI di Lampung terkendala biaya, tidak mendapatkan izin dari atasan langsung di tempat kerjanya, tidak mendapat izin dari keluarga,karena jarak yang jauh dan kemampuan berbahasa Arab yang masih kurang,

Menurut Slameto bahwa Faktor-faktor pribadi, yaitu umur dan tahap siklus hidup, pekerjaan, situasi ekonomi,gaya hidup, kepribadian dan konsep 
diri sangat berpengaruh terhadap studi lanjut. Terkendala biaya merupakan faktor situasi ekonomi yang tidak mendukung.

Tidak mendapat izin dari keluarga akan menjadi penghambat untuk lanjut studi. Dukungan keluarga diperlukan untuk memberikan pertolongan dan bantuan jika diperlukan. Dalam hal ini, penerima dukungan keluarga akan tahu bahwa ada orang lain yang memperhatikan, menghargai dan mencintainya. Menurut Sarafino, dukungan keluarga memiliki 5 jenis, yaitu: dukungan informasional, dukungan penghargaan, dukungan instrumental, dukungan kelompok dan dukungan emosional. Keempat dukungan tersebut diperlukan dalam lanjut studi.

\section{Simpulan}

Dari berbagai uraian latar belakang masalah, kajian teori serta paparan temuan hasil penelitian terkait dengan Minat Lulusan S1 PBA PTKI di Lampung Terhadap Lanjut Studi S2 PBA di Pascasarjana IAIN Metro, maka dapat disimpulkan hal-hal sebagai berikut:

1. Minat lulusan S1 Pendidikan Bahasa Arab PTKI di Lampung terhadap lanjut studi S2 Pendidikan Bahasa Arabdi Pascasarjana IAIN Metro karena adanya keinginan dari diri Alumni S1 PBA PTKI di Lampung untuk meningkatkan keilmuan mereka dalam bidang pendidikan dan pengajaran bahasa Arab dan juga karena adanya dukungan dari Orangtua mereka masing-masing.

2. Faktor pendukung minat lulusan S1 Pendidikan Bahasa Arab PTKI di Lampung terhadap lanjut studi S2 Pendidikan Bahasa Arabdi Pascasarjana IAIN Metroadalah adanya kesiapan biaya, kesiapan bahasa, dukungan orang tua, dukungan pihak sekolah dimana mereka mengajar serta faktor keinginan untuk meningkatkan ilmu dan Ibadah.

3. Faktor penghambat minat lulusan S1 Pendidikan Bahasa Arab PTKI di Lampung terhadap lanjut studi S2 Pendidikan Bahasa Arabdi Pascasarjana IAIN Metro karena Alumni S1 PBA PTKI di Lampung terkendala biaya, tidak mendapatkan izin dari atasan langsung di tempat kerjanya, tidak mendapat izin dari keluarga,karena jarak yang jauh dan kemampuan berbahasa Arab yang masih kurang.

\section{Referensi}

Abdurahman Shaleh dan Muhbib Abdul Wahab, Psikologi Suatu Pengantar dalam Perspektif Islam. Jakarta: Kencana, 2016

Abu Ahmadi dan Nur Uhbiyati, Ilmu Pendidikan, Jakarta: Rineka Cipta, 2017

Abu Ahmadi dan Widodo Supriyono, Psikologi Belajar, Jakarta: Rineka Cipta, 2004

Ahmad D. Marimba, Pengantar Filsafat Pendidikan Islam. Bandung: Al-Ma'arif, 1997

Bobbi De Porter \& Mike Hernachi, Quantum Learning: Membiasakan Belajar Nyaman dan Mentenangkan, Kaifa: Bandung, 2003 
Departemen Pendidikan Nasional, Undang-Undang No. 20 Sistem Pendidikan Nasional Tahun 2003, Jakarta, 2003

Elly M. Setiadi, dkk, Ilmu Sosial dan Budaya Dasar, Jakarta: Kencana, 2011

Loekmono, Belajar Bagaimana Belajar, Jakarta: BPK Gunung Mulia, 1994

Oemar Hamalik, Proses Belajar Mengajar, Jakarta: Bumi Akasara, 2004

Slameto, Belajar dan Faktor-Faktor yang Mempengaruhinya, Jakarta: Renika Cipta, 2013

Sudarmono, Tuntunan Metodologi Belajar, Jakarta: Grasindo, 1994

Sugeng Paranta, Psikologi Perkembangan, Jakarta: Angkasa, 2001

UUSPN No. 20 Tahun 2003

Zakiah Daradjat, Metodik Khusus Pengajaran Agama Islam, Jakarta: Bumi Aksara, 2014 